\title{
Dinamika Metode Pembelajaran Bahasa Arab
}

\author{
Mustafa \\ Institut Agama Islam Negeri (IAIN) Palopo, Sulawesi Selatan \\ e-mail: mustafa@iainpalopo.ac.id
}

\begin{abstract}
The method is one of the very important components of learning Arabic. It cannot be denied that the existence of methods greatly influences learning. One of the success factors of a learning process is a good method. The method is certainly supported by the competence of an educator in carrying it out. This paper aims to convey the dynamics of learning methods in a comprehensive manner. Some classical and modern methods that cannot be separated from learning Arabic, that is grammar and translation method, direct method, reading method, audiolingual method. All of these methods are still quite relevant to learning Arabic in the contemporary context. Learning Arabic cannot be separated from the translation process with the appropriate language rules. The same is true for the direct method, reading dan practice of listening and speaking the language.
\end{abstract}

Keywords: Dynamics, method, Arabic language learning

\begin{abstract}
Abstrak
Metode merupakan salah satu komponen pembelajaran bahasa Arab yang sangat penting. Tidak bisa dipungkiri bahwa keberadaan metode sangat memengaruhi sebuah pembelajaran. Salah satu faktor keberhasilan sebuah proses pembelajaran adalah metode yang baik. Metode tentu didukung oleh kompetensi seorang pendidik dalam menjalankannya. Tulisan ini bertujuan untuk menyampaikan dinamika metode pembelajaran secara komprehensif. Beberapa metode klasik dan modern yang tidak bisa dilepaskan dari pembelajaran bahasa Arab yaitu: Metode Tata Bahasa-Terjemah (Thariqah al-Qawa'id wa al-Tarjamah/Grammar and Translation Method), Metode Langsung (al-Thariqah al-Mubasyirah/Direct Method), Metode Membaca (Thariqah alQira'ah/Reading Method), Metode Dengar Ucap (al-Thariqah al-Sam 'iyyah al-Syafawiyyah/Audio-Lingual Method). Semua metode ini masih cukup relevan dengan pembelajaran bahasa Arab dalam konteks kekinian. Mempelajari bahasa Arab tidak terlepas dari proses penerjemahan dengan kaidah bahasa yang sesuai. Hal yang sama juga terjadi pada metode langsung, membaca dan latihan mendengar dan mengucapkan bahasa.
\end{abstract}

Kata Kunci: Dinamika, Metode, Pembelajaran Bahasa Arab 


\section{Loghat Arabi: Jurnal Bahasa Arab \& Pendidikan Bahasa Arab}

\section{Pendahuluan}

Dalam Undang-undang RI Nomor 20 Tahun 2003 tentang Sisdiknas (Sistem Pendidikan Nasional) dikatakan bahwa bahasa Indonesia sebagai bahasa negara menjadi bahasa pengantar dalam pendidikan nasional. ${ }^{1}$ Selanjutnya Undang-undang Sisdiknas juga menyinggung tentang bahasa asing, yaitu bahasa asing dapat digunakan sebagai bahasa pengantar pada satuan pendidikan tertentu untuk mendukung kemampuan berbahasa asing peserta didik. ${ }^{2}$ Sudah ada beberapa bahasa asing yang dijadikan mata pelajaran sekarang ini di sekolah-sekolah. Di antaranya adalah bahasa Arab, Inggris, Jerman, Mandarin, Jepang dan lain sebagainya. Dari semua bahasa di atas, hanya ada dua yang paling mendominanasi dalam pembelajaran bahasa. Kedua bahasa yang dimaksud adalah bahasa Inggris dan bahasa Arab. Bahasa terakhir yang disebutkan menjadi pembahasan dalam tesis ini.

Bahasa ini digunakan secara resmi oleh kurang lebih 20 negara. Karena ia merupakan bahasa kitab suci dan tuntunan agama umat Islam sedunia, maka tentu saja ia merupakan bahasa yang paling besar signifikansinya bagi ratusan juta muslim sedunia, baik yang berkebangsaan Arab maupun bukan. ${ }^{3}$ Bahasa Arab adalah bahasa yang tidak mungkin ditinggalkan. Sejak dulu sampai sekarang, bahasa Arab mempunyai keunggulan tersendiri dibanding bahasa lain. Bahkan salah seorang ulama bahasa, Ahmad bin Faris jauh sebelumnya sudah mengatakan dalam kitabnya bahwa bahasa Arab adalah bahasa yang paling mulia dan paling luas cakupan pembahasannya. ${ }^{4}$ Bahasa Arab merupakan bahasa surga dan bahasa kitab suci Alquran yang menjadi penutup kitab-kitab suci lainnya serta menjadi bahasa resmi di dunia internasional.

Pada saat sekarang ini, pembelajaran bahasa Arab sangatlah perlu ditopang oleh metode dalam mentransfer ilmu. Metode apapun yang digunakan dalam pembelajaran bahasa, jelas bahwa tujuan utamanya agar para peserta didik terampil atau mampu berbahasa. ${ }^{5}$ Mahmud Yunus dalam Azhar Arsyad mengatakan bahwa metode lebih penting dari substansi. ${ }^{6}$ Tetapi penguasaan materi atau substansi tidak bisa diabaikan. Keduanya saling membutuhkan.

\footnotetext{
${ }^{1}$ Undang-Undang RI Nomor 20 Tahun 2003 tentang Sistem Pendidikan Nasional (Cet. II; Jakarta: Sinar Grafika, 2009), h. 22.

${ }^{2}$ Undang-Undang RI Nomor 20 Tahun 2003 tentang Sistem Pendidikan Nasional, h. 23.

${ }^{3}$ Azhar Arsyad, Bahasa Arab dan Metode Pengajarannya (Cet. II; Yogyakarta: Pustaka Pelajar, 2003), h. 1 .

${ }^{4}$ Ahmad bin Faris, Al-Shahiby fi Fiqh al-Lugah al-'Arabiyyah wa Masailuha wa Sunan al-'Arab fi Kalamiha (Cet. I; Beirut: Maktabah al-Ma'arif, 1993 M/1414 H), h. 43.

${ }^{5}$ Henry Guntur Tarigan, Metodologi Pengajaran Bahasa Edisi ke I (Cet. I; Bandung: Angkasa, 1991), h. 7 .

${ }^{6}$ Henry Guntur Tarigan, Metodologi Pengajaran Bahasa, h. 66.
} 


\section{Loghat Arabi: Jurnal Bahasa Arab \& Pendidikan Bahasa Arab}

Muhammad 'Abdul Qadir Ahmad menjelaskan bahwa metode ada untuk membantu atau menjelaskan substansi. Tidak ada faidahnya dari metode yang baik tanpa adanya materi. Metodelah yang mengantar kepada pemahaman peserta didik terhadap materi. Oleh karena itu, metode dan materi adalah dua unsur yang sangat penting untuk keberhasilan guru dalam pembelajaran. ${ }^{7}$ Jelaslah bahwa tidak ada dikotomi antara metode dan materi (substansi).

Sebenarnya sebagian orang menganggap dengan salah satunya pembelajaran bisa berjalan. Tetapi harus dipahami, keduanya tak boleh dipisahkan dan harus berjalan seiring. Jika hal ini dilakukan, maka pembelajaran akan efektif dan tujuan akan tercapai. Terlebih lagi metode pembelajaran bahasa Arab telah mendapatkan perhatian dari pakar pembelajaran bahasa dengan melakukan berbagai kajian dan penelitian untuk mengetahui efektivitas dan kesuksesan berbagai metode pembelajaran. ${ }^{8}$

\section{Pengertian Pembelajaran Bahasa Arab}

Undang-undang Sistem Pendidikan Nasional Nomor 20 tahun 2003 menyatakan pembelajaran adalah proses interaksi peserta didik dengan pendidik dan sumber belajar pada suatu lingkungan belajar. ${ }^{9}$ Pembelajaran menurut Dimyati dan Mudjiono adalah kegiatan guru secara terprogram dalam intruksional, untuk membuat peserta didik belajar secara aktif yang menekankan pada penyediaan sumber belajar. ${ }^{10}$ Lebih lanjut Syaiful Sagala memaparkan karakteristik pembelajaran yang mencakup dua hal, yaitu: pertama, dalam proses pembelajaran melibatkan proses mental peserta didik secara maksimal, bukan hanya menuntut peserta didik sekedar mendengar, mencatat, akan tetapi menghendaki aktivitas peserta didik dalam proses berpikir. Kedua, dalam proses pembelajaran membangun suasana dialogis dan proses tanya jawab terus menerus yang diarahkan untuk memperbaiki dan meningkatkan kemampuan berpikir peserta didik, yang pada gilirannya kemampuan berpikir itu dapat membantu peserta didik untuk memperoleh pengetahuan yang mereka konstruksi sendiri. ${ }^{11}$

Adapun yang dimaksud pembelajaran bahasa Arab adalah suatu proses yang diarahkan untuk membina dan mengembangkan kemampuan peserta didik dalam menggunakan bahasa Arab, baik untuk memahami teks-teks keagamaan maupun sebagai alat komunikasi dan interaksi sosial secara lisan maupun tulisan.

\footnotetext{
7 Muhammad 'Abdul Qadir Ahmad, Thuruq Ta'lim al-Lugah al-'Arabiyyah (Cet. I; Kairo-Mesir: Maktabah an-Nahdhah al-Mishriyyah, 1979), h. 6.

${ }^{8}$ M. Abdul Hamid dkk, Pembelajaran Bahasa Arab: Pendekatan, Metode, Strategi, Materi dan Media (Cet. I; Malang: UIN-Malang Press, 2008), h. 1.

${ }^{9}$ Undang-Undang RI Nomor 20 Tahun 2003 tentang Sistem Pendidikan Nasional, h. 5.

${ }^{10}$ Dimyati dan Mudjiono, Belajar dan Pembelajaran (Jakarta: PT Rineka Cipta, 2006), h. 297.

${ }^{11}$ Syaiful Sagala, Pembelajaran Konsep dan Makna Pembelajaran (Cet.VII; Bandung: Alfabeta, 2010), h. 63 .
} 


\section{Tujuan dan Prinsip Pembelajaran Bahasa Arab}

a. Tujuan pembelajaran bahasa Arab

Pembelajaran sadar akan tujuan, artinya interaksi yang telah dicanangkan untuk tujuan tertentu. ${ }^{12}$ Dalam pembelajaran bahasa Arab ada dua tujuan, yaitu tujuan jangka panjang (tujuan umum) dan tujuan jangka pendek (tujuan khusus).

1) Tujuan umum pembelajaran bahasa Arab

Tayar Yusuf dan Syaiful Anwar menjelaskan tujuan umum (jangka panjang) pembelajaran bahasa Arab adalah:

a) Memahami Alquran dan hadis sebagai sumber hukum dan ajaran Islam.

b) Memahami buku agama dan kebudayaan Islam yang ditulis dengan bahasa Arab.

c) Supaya pandai berbicara dan mengarang menggunakan bahasa Arab.

d) Menggunakan bahasa Arab sebagai alat pembantu lainnya.

e) Menjadi ahli bahasa Arab yang profesional. ${ }^{13}$

2) Tujuan khusus pembelajaran bahasa Arab

Menurut Tayar Yusuf dan Syaiful Anwar, tujuan jangka pendek di antaranya: tujuan muhadatsah, tujuan mutala'ah, tujuan imla', tujuan insya' dan tujuan qawa'id. ${ }^{14}$

b. Prinsip pembelajaran bahasa Arab

Aktivitas pembelajaran dirancang mengikuti prinsip-prinsip pembelajaran dalam pembelajaran bahasa Arab. Pembelajaran bahasa Arab merupakan kegiatan aktif peserta didik dalam menemukan dan membangun makna atau pemahaman nilai-nilai yang terkandung dalam ajaran Islam. Menurut Aunurrahman, agar aktivitas yang dilakukan guru dalam proses pembelajaran terarah pada upaya peningkatan potensi peserta didik secara komprehensif, pembelajaran harus di-kembangkan sesuai dengan prinsip-prinsip yang benar, yang bertolak dari kebutuhan internal peserta didik. ${ }^{15}$ Prinsip-prinsip pembelajaran bahasa Arab pada hakikatnya sama dengan prinsip-prinsip pembelajaran bahasa asing yang lain. Kamal Ibrahim Badri dan Mamduh Nuruddin dalam Imam Makruf dengan mengutip dari buku "Principles of Language Study" menyebutkan

\footnotetext{
${ }^{12}$ Syaiful Sagala, Pembelajaran Konsep dan Makna Pembelajaran, h. 136.

13 Tayar Yusuf dan Saiful Anwar, Metodologi Pengajaran Agama dan Bahasa Arab (Jakarta: PT. RajaGrafindo, 1995), h. 189-190.

${ }_{14}$ Tayar Yusuf dan Saiful Anwar, Metodologi Pengajaran Agama dan Bahasa Arab, h. 190.

15 Aunurrahman, Belajar dan Pembelajaran (Cet. III; Bandung: Alfabeta, 2009), h. 113.
} 
adanya 5 prinsip dalam pembelajaran bahasa asing, yaitu: prioritas atau mendahulukan yang lebih utama, ketepatan, tahapan, aspek motivasi, baku dan mendasar. ${ }^{16}$

Prinsip-prinsip tersebut di atas secara singkat dapat dijelaskan sebagai berikut:

1) Prioritas atau mendahulukan yang lebih utama

Sebuah bahasa memiliki banyak bagian yang satu sama lain saling melengkapi. Meski demikian, dalam pembelajaran bahasa diperlukan adanya skala prioritas dengan mendahulukan sebagian atas sebagian yang lain.

2) Ketepatan

Setiap bahasa memiliki karakteristik masing-masing baik dalam bunyi, struktur, maupun makna konteks. Dengan demikian, pembelajaran bahasa Arab harus memerhatikan aspek ketepatan dalam hal bunyi (cara mengucapkan), struktur kalimat dan sesuai dengan konteksnya.

3) Tahapan

Maksud tahapan ini adalah meliputi hal-hal yang satu dengan yang lainnya saling melengkapi. Setiap tahapan merupakan landasan bagi tahapan berikutnya. Seperti mulai dari yang sudah diketahui sampai kepada yang belum diketahui atau mulai dari yang global sampai kepada yang terperinci.

4) Aspek motivasi

Di samping prinsip di atas, motivasi merupakan salah satu faktor penentu dalam pencapaian prestasi belajar bahasa Arab. Motivasi dapat dibangkitkan dari dalam diri peserta didik (motivasi intrinsik) dan dapat pula dibangkitkan dari luar (motivasi ekstrinsik).

5) Baku dan mendasar

Maksud dengan baku dan mendasar di sini adalah pembelajaran bahasa akan maksimal dengan cara menggunakannya, tidak hanya menjelaskan kaidahnya. Begitu juga dengan penerjemahan akan maksimal dengan menvisualisasikan sedapat mungkin dengan cara memberikan contoh-contoh.

\section{Metode Pembelajaran Bahasa Arab}

a. Metode Tata Bahasa-Terjemah (Thariqah al-Qawa id wa al-Tarjamah/Grammar and Translation Method)

\footnotetext{
${ }^{16}$ Imam Makruf, Bahasa Arab Aktif (Cet. I; Semarang: Need’s Press, 2009), h. 42.
} 
Metode gramatika dan terjemah ini juga sering disebut sebagai metode klasik (al-thariqah al-qadimah atau al-thariqah a-taqlidiyyah). Proses pembelajaran dengan metode ini adalah dengan melakukan analisis terhadap struktur kalimat dari sisi qawa'id dan menerjemahkannya.

Metode ini merupakan gabungan antara metode gramatika dengan metode menerjemah. Metode ini dapat dikatakan ideal daripada salah satu metode gramatika atau terjemahan. Karena kelemahan dari salah satu atau keduanya dari metode tersebut telah sama-sama saling menutupi dan melengkapi (jadi kedua-duanya dilakukan bersama-sama, serentak) artinya materi gramatika (tata bahasa) terlebih dahulu diajarkan dan kemudian pelajaran menerjemah, pelaksanaannya sejalan.

Berdasarkan pernyataan tersebut ada 2 aspek penting dalam metode kaidah dan terjemah: Pertama, kemampuan menguasai kaidah tata bahasa. Kedua, kemampuan menerjemahkan. Kedua, kemampuan ini adalah model dasar untuk mentransfer ide atau pikiran ke dalam tulisan dalam bahasa asing (mengarang) dan modal dasar untuk memahami ide atau pikiran yang dikandung tulisan dalam bahasa asing yang dipelajari (membaca pemahaman). ${ }^{17}$ Tujuan metode ini adalah agar para peserta didik pandai dalam menghafal dan memahami tata bahasa, mengungkapkan ide-ide dengan menerjemahkan dan membekali mereka agar mampu memahami teks bahasa asing dengan menerjemahkannya ke dalam bahasa sehari-hari atau sebaliknya.

Dalam pembelajaran bahasa Arab disuguhkan dalam pelajaran pendek gramatikal yang masing-masing berisi beberapa unsur atau kaidah tata bahasa yang diberi ilustrasi dan contoh-contoh. Ciri gramatikal yang difokuskan dalam buku pelajaran tidak disamarkan oleh guru. ${ }^{18}$

Dari beberapa penjelasan di atas dapat dikemukakan ciri-ciri utama metode tata bahasa dan terjemah antara lain adalah:

1) Metode ini memandang pembelajaran bahasa sebagai terdiri dari penghafalan kaidah-kaidah dan fakta-fakta tentang tata bahasa agar dapat dipahami dan dilakukan penerapan kaidah-kaidah itu pada morfologi dan sintaksis.

2) Penekanannya pada membaca, menulis dan menerjemahkan. Berbicara dan menyimak kurang diperhatikan.

17 Acep Hermawan, Metodologi Pembelajaran Bahasa Arab (Cet. I; Bandung: Remaja Rosdakarya, 2011), h. 171.

${ }^{18}$ Mansoer Pateda, Linguistik Terapan (Nusa Indah: t.p, t.th), h. 133. 
3) Seleksi kosakata berdasarkan teks-teks bacaan yang dipergunakan. Kosakata ini diajarkan melalui daftar-daftar dwibahasa dan penghafalan.

4) Tata bahasa diajarkan secara deduktif, yakni dengan penyajian kaidah-kaidah bahasa kemudian dilatih melalui terjemahan-terjemahan.

5) Bahasa peserta didik dipergunakan sebagai bahasa pengantar dalam terjemahan, perbandingan dan penghafalan kaidah-kaidah bahasa. ${ }^{19}$

Metode ini berdasarkan asumsi bahwa ada satu logika semesta yang merupakan dasar semua bahasa di dunia ini dan tata bahasa merupakan bagian dari filsafat dan logika. Belajar bahasa dengan demikian dapat memperkuat kemampuan berpikir logis, memecahkan masalah dan menghafal. ${ }^{20}$ Para pelajar bahasa dengan metode ini didorong untuk menghafal teks-teks klasik berbahasa asing dan terjemahannya dalam bahasa peserta didik, terutama teks-teks yang bernilai sastra tinggi, walaupun dalam teks itu seringkali terdapat struktur kalimat yang rumit dan kosakata atau ungkapan yang sudah terpakai.

Model silabus metode qawa'id tarjamah menekankan pembelajaran pada kosakata dan terjemah. Keterampilan membaca dan menulis adalah keterampilan yang diutamakan dalam pembelajaran. Hanya ada sedikit yang diberikan kepada keterampilan berbicara dan mendengarkan. Kalau pun ada, latihan pengucapan kata-kata sedikit sekali diberikan. Bahasa tulisan lebih diutamakan daripada bahasa lisan, karena itulah kemudian peserta didik mempelajarinya. Kultur dipandang sebagai bagian dari literatur dan seni. Bahan pelajaran bahasa disusun berdasarkan urutan tata bahasa pada bahasa sasaran. Biasanya urutan dari bahan pembelajaran disusun berdasarkan tingkat kemudahan tata bahasa. Silabus gramatikalnya diurutkan dari tata bahasa yang paling gampang sampai yang paling sulit. ${ }^{21}$

Untuk mengaplikasikan metode tata bahasa dan terjemah dalam pembelajaran bahasa asing, perlu dilihat asumsi dan silabus sebagaimana dijelaskan di atas agar tidak keluar dari karakteristik metode ini. Contoh penerapan metode yang mungkin dilakukan oleh guru bahasa Arab adalah sebagai berikut:

1) Pendahuluan, memuat berbagai hal yang berkaitan dengan materi yang akan disajikan baik berupa appersepsi atau tes awal tentang materi atau yang lainnya.

19 Sri Utari Subyakto-Nababan, Metodologi Pengajaran Bahasa (Jakarta: Gramedia Pustaka Utama, 1993), h. 12.

${ }^{20}$ Ahmad Fuad Effendy, Metodologi Pengajaran Bahasa Arab (Cet. III; Malang: Misykat, 2005), h. 31.

21 Aziz Fachrurrazi, Pembelajaran Bahasa Asing: Metode Tradisional Kontemporer (Cet. I; Jakarta Timur: Bania Publishing, 2010), h. 43-44. 
2) Pendidik memberikan pengenalan dan definisi kaidah-kaidah tertentu dalam bahasa Arab yang harus dihafalkan sesuai dengan materi yang akan disajikan, berikut terjemahannya dalam bahasa peserta didik. Contoh: Jika materi yang akan disajikan mengandung kaidah mubtada'-khabar maka langkah yang mungkin dilakukan adalah:

a) Mengenalkan konsep mubtada'-khabar berikut terjemahannya ke dalam peserta didik.

b) Memberikan contoh-contoh, jika diperlukan mengadakan perbandingan dengan kaidah bahasa peserta didik sehari-hari untuk membantu pemahaman para peserta didik.

c) Setelah itu pendidik menjelaskan contoh-contoh seperlunya, misalnya:

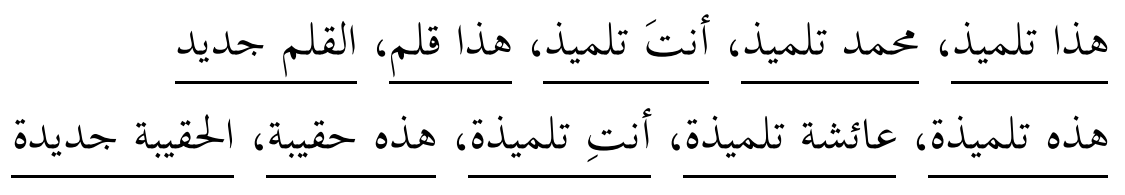

Dalam hal ini guru menjelaskan bahwa setiap dua kata yang digaris bawahi pada contoh-contoh itu merupakan pasangan mubtada'-khabar yang tidak boleh tertukar, kemudian dianalisis sampai i'rab-nya. Pendidik juga menjelaskan bahwa ada kategori muzakkar dan muannats yang masing-masing memiliki aturan berbeda.

d) Setelah para peserta didik benar-benar memahami konsep mubtad'-khabar, pendidik membimbing mereka untuk menghafalkan dengan disiplin.

3) Jika ada kosakata yang dipandang sulit untuk diterjemahkan, pendidik menjelaskan kosakata tersebut sebelum menginjak ke langkah aplikasi.

4) Pendidik memberikan materi teks bahasa Arab sebagai materi pokok (diambil dari buku pegangan), lalu mengajak peserta didik untuk menerjemahkan kata demi kata, kalimat demi kalimat sampai ke paragraf demi paragraf. Para peserta didik setelah itu disuruh untuk mencocokkan kaidah-kaidah yang telah dihafalkan dengan teks baru itu. Dalam hal ini diharapkan mereka dapat mengidentifikasi mubtada'-khabar sebagaimana mubtada'-khabar yang mereka hafalkan lalu menganalisis sampai detail.

5) Setelah para peserta didik selesai memahami mubtada'khabar dengan baik, pendidik memberi daftar kosakata untuk dihafalkan. Kata-kata itu lepas dari 
konteks kalimat dan pendidik menyuruh para peserta didik untuk memberi terjemahan kosakata itu.

6) Sebagai kegiatan akhir, pendidik memberi pekerjaan rumah berupa persiapan terjemahan untuk dibahas pada pertemuan berikutnya.

Contoh di atas tentu saja tidak menjadi suatu kepastian, sebab selanjutnya diserahkan kepada pendidik sesuai situasi dan kondisi dengan catatan tidak bertentangan dengan asumsi dan silabus metode ini.

Ada dua hal yang menguntungkan melalui metode ini, yaitu:

1) Tanpa disadari peserta didik memperoleh pengetahuan dari keduanya (tata bahasa dan terjemah) dengan pengetahuan menjadi utuh.

2) Meskipun siswa belum dapat lancar bercakap-cakap dalam berkomunikasi bahasa asing, akan tetapi peserta didik paling tidak dapat berbahasa pasif artinya dapat membaca dan menerjemahkan buku-buku bacaan. ${ }^{22}$

Namun demikian, metode ini tetap memiliki kelemahan karena pengajarannya hanya dapat membimbing peserta didik terampil berbahasa pasif dan tidak aktif. Sedangkan pengertian utama dari berbahasa ialah berbicara lisan atau bercakap-cakap. ${ }^{23}$

Secara rinci Acep Hermawan mengungkapkan diantara kelebihan dan kekurangan metode ini adalah sebagai berikut:

\section{Kelebihannya:}

1) Para peserta didik bisa hafal kosakata dalam jumlah yang relatif banyak dalam setiap pertemuan.

2) Para peserta didik mahir menerjemahkan dari bahasa asing ke dalam bahasa seharihari atau sebaliknya.

3) Para peserta didik dapat hafal kaidah-kaidah bahasa asing yang disampaikan dalam bahasa sehari-hari karena senantiasa menggunakan terjemahan dalam bahasa seharihari.

\section{Kekurangannya:}

1) Analisis bahasa mungkin baik bagi mereka yang merancangnya, akan tetapi tidak menutup kemungkinan dapat membingunkan para peserta didik karena rumitnya analisis itu.

\footnotetext{
${ }^{22}$ Ahmad Izzan, Metodologi Pembelajaran Bahasa Arab (Cet. II; Bandung: Humaniora, 2007), h. 117.

${ }^{23}$ Ahmad Izzan, Metodologi Pembelajaran Bahasa Arab, h.117.
} 


\section{Loghat Arabi: Jurnal Bahasa Arab \& Pendidikan Bahasa Arab}

2) Terjemahan kata demi kata, kalimat demi kalimat sering mengacaukan makna kalimat dalam konteks yang luas.

3) Para peserta didik mendapat pelajaran dalam satu ragam tertentu, sehingga mereka kurang mengenal ragam-ragam lainnya yang lebih luas. Oleh karena itu tingkat kebermaknaannya dalam kehidupan sehari-hari menjadi minim.

4) Para peserta didik menghafal kaidah-kaidah bahasa yang disajikan secara preskriptif. Mungkin saja kaidah-kaidah itu tidak berlaku bagi bahasa sehari-hari. ${ }^{24}$

b) Metode Langsung (al-Thariqah al-Mubasyirah/Direct Method)

Menjelang pertengahan abad ke-19 ada beberapa faktor yang menyebabkan penolakan atau ketidakpuasan metode tata bahasa dan terjemahan. Dari sinilah kemudian membuka jalan untuk penggunaan metode baru. Menurut Henry Guntur Tarigan bahwa penggunaan-penggunaan inilah yang memunculkan pembaharuanpembaharuan yang mempunyai berbagai nama yaitu metode pembaharuan (reform method), metode alamiah (natural method), metode psikologis (psychological method), metode fonetik (phonetic method) dan sebagainya, tetapi istilah yang lebih mantap untuk memberikan ciri-ciri yang beraneka ragam bagi pendekatan-pendekatan baru dalam pengajaran bahasa ini adalah metode langsung. ${ }^{25}$

Meskipun metode ini dikatakan sebagai reaksi kuat terhadap metode tata bahasa terjemahan, tetapi sebenarnya orang telah menggunakan metode langsung ini dalam pengajaran bahasa tujuan sejak zaman Romawi (kira-kira abad ke-15) ketika para pemuda Romawi diberi pelajaran dari guru-guru Yunani untuk belajar bahasa Yunani. ${ }^{26}$

Mubasyirah atau direct artinya langsung. Metode ini menyajikan materi pembelajaran bahasa asing di mana guru langsung menggunakan bahasa asing tersebut sebagai bahasa pengantar dan tanpa menggunakan bahasa peserta didik sedikit pun dalam mengajar. Jika ada kata-kata yang sulit dimengerti peserta didik, guru dapat mengartikan dengan menggunakan alat peraga, mendemonstrasikan, menggambarkan dan lain-lain.

Metode ini berpijak dari pemahaman bahwa pengajaran bahasa asing tidak sama halnya mengajar dengan ilmu pasti atau ilmu alam. Jika mengajar ilmu pasti, peserta didik dituntut agar dapat menghafal rumus-rumus tertentu, berpikir dan mengingat.

\footnotetext{
${ }^{24}$ Acep Hermawan, Metodologi Pembelajaran Bahasa Arab, h. 175.

${ }^{25}$ Henry Guntur Tarigan, Metodologi Pengajaran Bahasa Edisi ke 1 (Cet. I; Bandung: Angkasa, 1991),

${ }^{26}$ Sri Utari Subyakto-Nababan, Metodologi Pengajaran Bahasa, h. 15.
} h. 107. 


\section{Loghat Arabi: Jurnal Bahasa Arab \& Pendidikan Bahasa Arab}

Dalam pengajaran bahasa, peserta didik dilatih praktik langsung mengucapkan kata-kata atau kalimat-kalimat tertentu. Sekalipun kata-kata atau kalimat tersebut awalnya masih asing dan tidak dipahami peserta didik, namun sedikit demi sedikit kata-kata dan kalimat-kalimat itu akan dapat diucapkan dan dapat pula mengartikannya. ${ }^{27}$

Pada prinsipnya, metode langsung ini sangat utama dalam mengajar bahasa asing, karena melalui metode ini peserta didik dapat langsung melatih kemahiran lidah tanpa menggunakan bahasa ibu (bahasa lingkungannya). Meskipun pada mulanya terlihat sulit untuk menirukannya, akan tetapi metode ini menarik bagi peserta didik.

Metode ini dikembangkan atas dasar asumsi bahwa proses belajar bahasa kedua atau bahasa asing sama dengan belajar bahasa ibu, yaitu dengan penggunaan bahasa secara langsung dan intensif dalam komunikasi dengan menyimak dan berbicara sedangkan mengarang dan membaca dikembangkan kemudian. Oleh karena itu, peserta didik harus dibiasakan berpikir dalam bahasa target dan penggunaan bahasa ibu peserta didik dihindari sama sekali. ${ }^{28}$

Silabus yang digunakan dalam metode langsung didasarkan pada berbagai situasi (seperti: satu unit akan berisi dari ungkapan-ungkapan di bank dan unit yang lain berisi ungkapan-ungkapan ketika berbelanja) atau berbagai topik (seperti: geografi, uang atau cuaca). Tata bahasa diajarkan secara induktif, yaitu para peserta didik diperkenalkan dengan contoh-contoh terlebih dahulu lalu mereka berusaha memahami kaidah-kaidah atau generalisasi kaidah yang berada di balik contoh-contoh tersebut. Aturan tata bahasa yang tegas (eksplisit) tidak boleh diberi. Para peserta didik mempraktikkan kosakata dengan menggunakan kata-kata baru tersebut dalam kalimat-kalimat lengkap. Dengan demikian pemilihan materi ajar lebih ditekankan pengajaran kosakata daripada tata bahasa. $^{29}$

c. Metode Membaca (Thariqah al-Qira'ah/Reading Method)

Metode qira'ah merupakan metode pembelajaran bahasa yang bertujuan untuk memberikan kemampuan membaca secara mudah kepada peserta didik. Tujuan lebih jauh dari metode ini adalah agar peserta didik memiliki pengetahuan dan bekal yang cukup tentang berbagai bentuk kalimat yang benar sehingga memudahkan dalam menulis (kitabah) dan dapat diwujudkan dalam bentuk ucapan ketika melakukan percakapan ( kalam).

\footnotetext{
${ }^{27}$ Ahmad Izzan, Metodologi Pembelajaran Bahasa Arab, h. 100.

${ }^{28}$ Ahmad Fuad Effendy, Metodologi Pengajaran Bahasa Arab, h. 35.

${ }^{29}$ Aziz Fachrurrazi, Pembelajaran Bahasa Asing: Metode Tradisional Kontemporer, h. 55.
} 


\section{Loghat Arabi: Jurnal Bahasa Arab \& Pendidikan Bahasa Arab}

Metode ini dipilih lebih kepada alasan akademis, karena biasanya metode ini digunakan untuk tujuan tertentu. Metode juga ini lebih ditujukan bukan untuk mereka yang ingin bepergian keluar negeri, tetepi lebih ditujukan untuk mereka yang menggunakan bacaan dalam bahasa target. Prioritas dalam pembelajaran ini adalah: pertama, membaca dalam bahasa target. Kedua, sejarah atau kejadian historis negara di mana bahasa target digunakan. Ketiga, metode ini tidak begitu memberikan perhatian kepada pronunciation. Sejak awal peserta didik sudah dibiasakan untuk banyak membaca dalam bahasa target. Metode ini lebih mementingkan kosakata. Kosakata diberikan sejak awal dan terus berkembang sesuai dengan tingkat kesulitan teks.

Metode ini lahir pada tahun 1920-an disebabkan adanya ketidakpuasan di kalangan para pendidik dan ahli bahasa terhadap metode langsung yang kurang memberikan perhatian kepada keterampilan membaca dan menulis. ${ }^{30}$ Metode ini mulai digunakan dalam tahun 1929-an di sekolah-sekolah menengah maupun perguruan tinggi di seluruh Amerika Serikat. Di banyak negeri di luar Amerika Serikat, metode membaca ini mulai digunakan. Di antara tujuannya ialah memberi peserta didik dan mahasiswa kemampuan untuk memahami yang mereka perlukan dalam studi mereka. Tujuan ini belum dirumuskan secara jelas dalam tahun-tahun 1929-an itu, tetapi lambat laun metode membaca mempunyai tujuan yang dirumuskan di atas. ${ }^{31}$

Metode ini dikembangkan berdasarkan asumsi bahwa pengajaran bahasa tidak bisa bersifat multi-tujuan dan bahwa kemampuan membaca adalah tujuan yang paling realistis ditinjau dari kebutuhan orang yang mempelajari bahasa asing. Dengan demikian, asumsinya bersifat pragmatis, bukan filosofis teoretis. ${ }^{32}$

Silabus dalam metode ini didasarkan pada materi pelajaran yang terdiri dari bacaan-bacaan yang dibagi menjadi beberapa bagian pendek, di mana pada bagianbagian pendek tersebut selalu didahului dengan daftar kata-kata yang maknanya bisa diajarkan melalui konteks, terjemahan atau gambar-gambar. Buku-buku bacaan yang ditetapkan harus bertingkat-tingkat dari yang mudah/sederhana ke yang lebih sulit/kompleks dan dari apa yang mudah diketahui ke hal-hal yang belum dikuasai dengan menggunakan kosakata yang intensitas penggunaannya tinggi (almufradat alsyai'ah al-isti'mal). ${ }^{33}$

\footnotetext{
${ }^{30}$ Aziz Fachrurrazi, Pembelajaran Bahasa Asing: Metode Tradisional Kontemporer, h. 63.

${ }^{31}$ Sri Utari Subyakto-Nababan, Metodologi Pengajaran Bahasa, h. 19-20.

32 Ahmad Fuad Effendy, Metodologi Pengajaran Bahasa Arab, h. 41.

${ }^{33}$ Aziz Fachrurrazi, Pembelajaran Bahasa Asing: Metode Tradisional Kontemporer, h. 67.
} 
d. Metode Dengar Ucap (al-Thariqah al-Sam'iyyah al-Syafawiyyah/Audio-Lingual Method)

Metode audio-lingual pada dasarnya merupakan pengembangan dari metode langsung yang dirasa memiliki kelemahan terutama dalam menjelaskan hal-hal yang sulit dipahami peserta didik. Untuk itu metode ini di samping menekankan pengajaran bahasa lewat mendengar dan menirukan, juga dimungkinkan penggunaan bahasa ibu untuk penjelasannya. Metode ini biasanya lebih banyak diterapkan dengan bentuk pattera drill. Penggunaan pendekatan dril sudah lazim digunakan di kalangan militer. Karena pada awalnya metode ini banyak digunakan pada kalangan militer maka metode ini juga disebut dengan army method.

Metode audio-lingual sering disebut pendekatan dengar ucap (aural-oral approach) atau metode meniru-menghafal (the mimicry-memorization method) atau metode informan-dril (the informant-drill method). ${ }^{34}$

Metode ini didasari pada prinsip psikologi tingkah laku. Metode ini mengadaptasi prinsip-prinsip dari metode langsung dan juga metode bacaan yang tidak begitu mementingkan keterampilan berbicara peserta didik. Materi diberikan dalam bentuk dialog. Metode ini juga menekankan pada mimicry dan memorization pada saat pembelajaran. Tata bahasa diajarkan secara parsial dengan menggunakan metode pengulangan. Penjelasan tentang tata bahasa hanya diberikan sedikit atau bahkan tidak sama sekali. Pengajaran ditentukan oleh analisis perbedaan antara bahasa ibu dengan bahasa target. Metode ini sering menggunakan laboratorium bahasa, kaset dan media lainnya, karena metode ini lebih menekankan pada pentingnya pengucapan yang mirip dengan penutur asli. Peserta didik disarankan menggunakan bahasa ibu seminim mungkin untuk meningkatkan keterampilan berbicara mereka dalam bahasa target.

Metode audio-lingual itu diterima dengan terbuka oleh para aktivis pengajar bahasa Arab untuk non-Arab. Penerimaan ini disebabkan oleh banyak hal. Tiga di antaranya yang paling asasi adalah:

1) Tersebarnya metode audio-lingual karena memiliki hubungan erat dengan metode structural behavior. Metode ini juga telah mendominasi bidang pembelajaran bahasa asing secara umum dan bertetapan dengan mulai digalakkannya

\footnotetext{
${ }^{34}$ Mansoer Pateda, Linguistik Terapan, h. 137.
} 


\section{Loghat Arabi: Jurnal Bahasa Arab \& Pendidikan Bahasa Arab}

pembelajaran bahasa Arab untuk non-Arab, baik di dalam maupun di luar dunia Arab.

2) Metode audio-lingual muncul sebagai metode yang paling populer di bidang pengajaran bahasa yang hidup. Metode ini bukan sebagai teori bahasa yang terbatas pada teori, seperti mendeskripsikan dan menganalisis. Artinya, metode audio-lingual ini memasuki bahasa Arab dari sektor pembelajaran, bukan dari sektor bahasa sebagai teori.

3) Para linguis yang menggunakan program-program ini merasa puas dengan konsep-konsep yang dibawa oleh teori ini, yaitu teori struktural-deskriptif yang menyatu dengan pandangan behaviorisme. ${ }^{35}$

Asumsi metode audio-lingual didasarkan atas beberapa asumsi antara lain bahwa bahasa itu awalnya adalah ujaran. Oleh karena itu pengajaran harus dimulai dengan memperdengarkan bunyi-bunyi bahasa dalam bentuk kata atau kalimat kemudian mengucapkannya, sebelum pelajaran membaca dan menulis. Asumsi lain dari metode ini adalah bahwa bahasa adalah kebiasaan. Suatu perilaku akan menjadi kebiasaan apabila diulang berkali-kali. Oleh karena itu, pengajaran bahasa harus dilakukan dengan teknik pengulangan atau repitisi. ${ }^{36}$

Struktur bahan ajar bahasa dengan metode ini menekankan pada penguasaan seluruh komponen bahasa. Silabus yang digunakan oleh metode ini pada umumnya silabus struktural, dengan pembelajaran beberapa struktur bahasa pada setiap unit pembahasan yang tercakup dalam dialog baru. Kosakata yang diajarkan disesuaikan dengan konteks dialog. Jumlah kosakata tersebut dibatasi karena metode ini terletak pada pemerolehan pola-pola bahasa. ${ }^{37}$

\section{Simpulan}

Pembelajaran bahasa Arab merupakan salah satu proses untuk mendalami dan mempraktikkan bahasa Arab. Seorang pelajar harus bersemangat mempelajarinya. Pendidik pun diharuskan lebih bersemangat mengajarkannya. Dalam mencapai hasil belajar yang maksimal diperlukan metode yang baik. Cara yang dipergunakan berjalan sistematis. Hal yang

35 Abdul Aziz bin Ibrahim al-Ushaili, al-Nadzariyyah al-Lugawiyyah wa Ta'lim al-Lugah al'Arabiyyah, terj. Jailani Musni, Psikolinguistik Pembelajaran Bahasa Arab (Cet. I; Bandung: Humaniora, 2009), h. 59.

${ }^{36}$ Ahmad Fuad Effendy, Metodologi Pengajaran Bahasa Arab, h. 46-47.

${ }^{37}$ Aziz Fachrurrazi, Pembelajaran Bahasa Asing: Metode Tradisional Kontemporer, h. 77. 


\section{Loghat Arabi: Jurnal Bahasa Arab \& Pendidikan Bahasa Arab}

paling penting adalah ketepatan metode dengan materi dan keadaan pelajar bahasa. Metode yang teratur dalam pembelajaran akan menghasilkan pembelajaran yang efektif.

Berbagai macam metode mengiringi pembelajaran bahasa Arab. Setiap pendidik dalam menyampaikan materinya berbeda caranya. Menyesuaikan dengan kemampuan dan keahlian yang dimiliki. Hanya saja pendidik tidak bisa memilih satu metode saja dalam pembelajaran. Dari beraneka ragam metode yang muncul, beberapa di antaranya masih dipergunakan dalam setiap generasi. Metode-metode yang dimaksud adalah metode kaidah dan menerjemahkan, metode langsung, metode membaca dan metode dengar ucap.

Dinamika metode pembelajaran bahasa Arab merupakan keadaan yang tidak bisa dihindari. Metode tidak akan jalan jika bersifat konstan. Pembelajaran bahasa Arab tidak mendapatkan hasil yang baik jika metode yang dipergunakan tetap dan tidak mengalami pembaruan. Beberapa metode yang disebutkan di atas mengalami perkembangan. Metode kaidah terjemah yang sudah muncul sejak dahulu mampu menyesuaiakan dengan keadaan sekarang. Masih terpakai dan tidak bisa ditinggalkan dalam pembelajaran bahasa Arab. Metode bahasa Arab masih bertahan dengan nama tertentu tetapi tidak menafikan modifikasi atau perubahan.

\section{Daftar Rujukan}

Ahmad bin Faris, Al-Shahiby fi Fiqh al-Lugah al-'Arabiyyah wa Masailuha wa Sunan al'Arab fi Kalamiha, Cet. I; Beirut: Maktabah al-Ma arif, 1993 M.

Ahmad, Muhammad 'Abdul Qadir, Turuq Ta'lim al-Lugah al-'Arabiyyah, Cet. I; QairoMesir: Maktabah an-Nahdah al-Misriyyah, 1979.

Arsyad, Azhar, Bahasa Arab dan Metode Pengajarannya, Cet. II; Yogyakarta: Pustaka Pelajar, 2003.

Effendy, Ahmad Fuad, Metodologi Pengajaran Bahasa Arab, Cet. III; Malang: Misykat, 2005.

Fachrurrazi, Aziz, Pembelajaran Bahasa Asing; Metode Tradisional Kontemporer, Cet. I; Jakarta Timur: Bania Publishing, 2010.

Hamid, M. Abdul, Pembelajaran Bahasa Arab; Pendekatan, Metode, Strategi, Materi dan Media, Cet. I; Malang: UIN-Malang Press, 2008.

Hermawan, Acep, Metodologi Pembelajaran Bahasa Arab, Cet. I; Bandung: Remaja Rosdakarya, 2011.

Izzan, Ahmad, Metodologi Pembelajaran Bahasa Arab, Cet. II; Bandung: Humaniora, 2007.

Pateda, Mansoer, Linguistik Terapan, Nusa Indah: t.p, t.th.

Subyakto-Nababan, Sri Utari, Metodologi Pengajaran Bahasa, Jakarta: Gramedia Pustaka Utama, 1993.

Tarigan, Henry Guntur, Metodologi Pengajaran Bahasa, Edisi ke I. Cet. I; Bandung: Angkasa, 1991. 
Undang-Undang RI Nomor 20 Tahun 2003 tentang Sistem Pendidikan Nasional, Cet. II; Jakarta: Sinar Grafika, 2009.

Al-Ushaili, Abdul Aziz bin Ibrahim, al-Nadzariyyah al-Lugawiyyah wa Ta lim al-Lugah al'Arabiyyah, Terj. Jailani Musni, Psikolinguistik Pembelajaran Bahasa Arab, Cet. I; Bandung: Humaniora, 2009. 